\title{
Corrigendum
}

\section{A participatory approach in agricultural development: A case study of a Research-Education-Development project to optimise mixed farming systems in Guadeloupe (FWI) - CORRIGENDUM}

Stark Fabien, Alexandre Régis, Diman Christiane, Alexandre Gisèle, Diman Jean Louis and Archimede Harry

doi:10.1017/S2040470010001238; published by Cambridge University Press, 8 November 2010

In the abstract by Stark Fabien, Alexandre Régis, Diman Christiane, Alexandre Gisèle, Diman Jean Louis and Archimede Harry (2010) presented in Advances in Animal Biosciences, the author names were listed incorrectly with the authors' given names and family names in the wrong sequence. The correct authorship is:

Fabien Stark, Régis Alexandre, Christiane Diman, Gisèle Alexandre, Jean Louis Diman and Harry Archimede The editors apologise to the authors and readers for this mistake.

\section{Reference}

Fabien S, Régis A, Christiane D, Gisèle A, Jean Louis D and Harry A 2010. A participatory approach in agricultural development: A case study of a Research-EducationDevelopment project to optimise mixed farming systems in Guadeloupe (FWI). Advances in Animal Biosciences 1, 507-508. 